\title{
Effect of testosterone and dibutyryl cAMP on the spontaneous maturation of pig oocytes
}

\author{
Catherine Rice and R. W. McGaughey \\ Department of Zoology, Arizona State University, Tempe, Arizona 85281, U.S.A.
}

\begin{abstract}
Summary. This study was undertaken to develop a system that simulated, to some extent, the environment of the immature follicle and which reversibly inhibited the spontaneous maturation of porcine oocytes. The hypothesis was tested that a physiological concentration of testosterone $(0.5 \mu \mathrm{M})$ in the presence of the cyclic nucleotide derivative, dibutyryl cAMP ( $1 \mathrm{mM})$, would prevent germinal vesicle breakdown and subsequent chromatin condensation of intact oocytes. Liberated cumulus-enclosed (intact) and cumulus-free (denuded) oocytes were cultured in a complex serum-based medium supplemented with the steroid and/or the nucleotide analogue. After $24 \mathrm{~h}$, chromatin spreads were prepared and meiotic maturation was scored.

In the presence of testosterone or dibutyryl cAMP, meiotic maturation of intact oocytes was similarly and significantly inhibited (57 and $58 \%$ matured, respectively) compared with controls ( $74 \%$ matured). This inhibition, however, was not nearly as marked as when both compounds were present together (19\% matured), indicating a synergistic inhibitory relationship between the steroid and nucleotide. The inhibition exerted by the two compounds on the intact oocyte was reversible, a finding consistent with the observation that fewer germinal vesicles were degenerate in 'inhibited' oocytes than in oocytes cultured in control, unsupplemented medium. Although maturation of denuded oocytes was likewise inhibited by testosterone + dibutyryl cAMP (15\% matured compared with $68 \%$ in control medium), this inhibition was due to a direct action of the cAMP derivative on the oocyte, with testosterone playing a passive role. These results suggest, therefore, that the cumulus cell mediated the inhibitory action of testosterone and dibutyryl cAMP on the maturation of the intact oocyte. In the light of reports that FSH or cAMP stimulate aromatase activity in cultured granulosa cells, our results suggest that oestrogen may be implicated in the observed inhibition of oocyte maturation.
\end{abstract}

\section{Introduction}

Arrest of mammalian oocytes at the germinal vesicle (GV) stage of meiosis is currently considered to be due to a follicular inhibitor, the effect of which is overridden upon exposure of the follicle to LH (reviewed by Tsafriri, 1978). The most compelling evidence in support of this concept is derived from the observation that mammalian oocytes spontaneously resume meiosis in vitro when removed from antral follicles (reviewed by Donahue, 1972). The nature of this follicular inhibitor is not well established, although available evidence suggests that it may be a follicular fluid peptide of low molecular weight (Jagiello, Graffeo, Ducayen \& Prosser, 1977; Stone, Pomerantz, Schwartz-Kripner \& Channing, 1978), an oestrogenic steroid (McGaughey, 
1977a; Richter \& McGaughey, 1979), or a cyclic nucleotide (Wassarman \& Turner, 1976; Dekel \& Beers, 1978).

The immature follicle is dominated by a high level of oestradiol relative to that of progesterone (Gérard, Ménézo, Rombauts, Szöllösi \& Thibault, 1979; reviewed by McNatty, 1979) as a result of high aromatase activity in granulosa cells when stimulated by FSH (Lacroix, Eechante \& Leusen, 1974; Dorrington, Moon \& Armstrong, 1975; Armstrong, Goff \& Dorrington, 1979), the action of which is mediated by cAMP (Erickson \& Ryan, 1975; Anderson, Schaerf \& Channing, 1979; Lindsey \& Channing, 1979). Since oestradiol has been shown to inhibit the spontaneous maturation of porcine oocytes (McGaughey, 1977a; Richter \& McGaughey, 1979), we advanced the hypothesis that intact oocytes (i.e. oocytes with granulosa cells) would not mature in the presence of androgen and the cAMP derivative, $\mathrm{N}^{6}, \mathrm{O}^{2}$-dibutyryl adenosine $3^{\prime}, 5^{\prime}$-cyclic monophosphoric acid (dbcAMP). The results of the experiments designed to test this hypothesis are presented in this paper.

\section{Materials and Methods}

\section{Collection of oocytes}

Reproductive tracts were obtained from a local abattoir within a few minutes of slaughter. The ovaries from 4 or more gilts provided oocytes for an individual experiment. In experiments with two groups (control and experimental), selected oocytes from one ovary served as the controls for experimental oocytes from the contralateral ovary. For experiments with four groups, the ovaries from each tract were halved, and each half-ovary was used to provide oocytes for one treatment group. Oocytes were collected from medium-sized antral follicles (3-5 $\mathrm{mm}$ diameter), by vigorously puncturing the ovary with a sterile 18 gauge needle, into BMOC-3 medium (Brinster, 1971) modified to contain dextran T-70 $(4.5 \mathrm{mg} / \mathrm{ml}$; Pharmacia) as described by McGaughey (1977b). Only oocytes with an intact, tightly adherent mass of corona radiata cells (intact oocytes) were selected for subsequent experiments. Denuded (cumulus-free) oocytes were obtained by mechanically removing cumulus cells from intact oocytes with a small-bore pipette (Hillensjö, Hamberger \& Ahrén, 1975; McGaughey \& Van Blerkom, 1977). When required, the detached cumulus cells were collected into a sterile tube (Falcon Plastics $15 \times 75$ $\mathrm{mm}$; No. 2058), centrifuged into a pellet at $500 \mathrm{~g}$ for $5 \mathrm{~min}$, re-suspended in a minimal volume of culture medium, washed, re-centrifuged and transferred to the culture vessel. All oocytes were washed successively three times in the appropriate medium before culture. The collection of oocytes and preparation of cultures usually took between $1 \frac{1}{2}$ and $2 \mathrm{~h}$, and never longer than $2 \frac{1}{2} \mathrm{~h}$.

\section{Culture procedures}

The oocytes were cultured in wells of Lab-Tek chamber slides (No. 4838) in $0.4 \mathrm{ml}$ medium under $5 \% \mathrm{CO}_{2}$ in humidified air in a desiccator at $37^{\circ} \mathrm{C}$ for $24 \mathrm{~h}$. The complex medium of Tsafriri \& Channing (1975) was used. This medium (TCM) consisted of Medium 199 with Earle's salts and $12 \mathrm{mM}$-HEPES buffer supplemented with $15 \%$ pig serum, $1 \mathrm{~mm}$-glutamine, 2.5 mM-lactate, $0.03 \mathrm{~mm}$-pyruvate, $12.5 \mathrm{mU}$ insulin $/ \mathrm{ml}$ and $50 \mu \mathrm{g}$ gentamicin $/ \mathrm{ml}$. Stock solutions ( $\times 1000)$ of insulin and sodium pyruvate were prepared in Medium 199, divided into appropriate aliquots and stored frozen at $-20^{\circ} \mathrm{C}$. The serum was likewise stored in suitable aliquots. Media were made up routinely the evening before an experiment. Prepared TCM medium was supplemented with dbcAMP and/or testosterone. Stock solutions of each compound were prepared: dbcAMP (1 M; Sigma) was prepared in Medium 199 and stored in aliquots at $-20^{\circ} \mathrm{C}$ and testosterone $\left(500 \mu \mathrm{M}\right.$; Schwarz/Mann) was prepared in absolute ethanol and stored at $4^{\circ} \mathrm{C}$. Medium containing the appropriate concentration of dbcAMP was prepared, sterilized by filtration through a Millipore filter $(0.45 \mu \mathrm{M})$ and, when required, an appropriate volume of 
testosterone stock was carefully added aseptically. Steroid-containing medium was never filtered since Millipore filters avidly bind steroids. The concentration of ethanol never exceeded $1 \mu \mathrm{l} / \mathrm{ml}$. An equivalent volume of ethanol was added to media which did not contain testosterone. All media were equilibrated to culture conditions for at least $2 \mathrm{~h}$ before use. Groups of 10-15 oocytes were cultured in each well. Within an experiment at least two replicates were provided for each treatment, and each experiment was normally repeated at least 3 times. After culture, all oocytes were denuded, air-dried as described previously (McGaughey \& Polge, 1971), and stained with $0.29 \%(\mathrm{w} / \mathrm{v})$ Wright's stain in $2.9 \%(\mathrm{v} / \mathrm{v})$ glycerol and $97.1 \%$ methanol. Oocyte maturation was scored as reported previously (McGaughey, 1977a, 1978). Viability tests were carried out on cumulus cell masses using the trypan blue exclusion test of Merchant, Kahn \& Murphy (1961).

\section{Statistical analyses}

Meiotic maturation of examined oocytes was classified as follows: (1) those that had remained at the germinal vesicle (GV) stage (immature), and (2) those that had developed beyond the GV stage (diakinesis to metaphase II). The first classification was subdivided into (i) the proportion of GVs that were degenerate as defined by McGaughey, Montgomery \& Richter (1979), and (ii) the proportion of GVs that were normal (fibrous or diffuse; McGaughey et al., 1979). The second classification was subdivided into (i) the proportion of oocytes which reached metaphase I, and (ii) the proportion of oocytes that reached metaphase II. For each culture well, the proportions of oocytes in each of the above classifications were transformed to angles and analysed by the Duncan Multiple Range Test using the SPSS computer program (Nie, Hull, Jenkins, Steinbrenner \& Brent, 1975; McGaughey, 1978). Significant differences among experimental and control groups were approximated at alpha $=0.05$. Group means and their $95 \%$ confidence intervals were transformed back to percentages for tabulation. The Duncan Multiple Range Test has been used because, in comparison to other statistical tests, it employs decreasing significant differences and protection levels based on degrees of freedom (Duncan, 1955).

\section{Experimental protocols}

Experiment 1. This experiment was carried out to validate the culture system. Oocytes were cultured for $24 \mathrm{~h}$ in TCM and subsequently scored for maturation. Viability studies were carried out on 4 separate cultures of cumulus cells.

Experiment 2. The effect of the addition of $0 \cdot 01,0.1$ or $1 \mathrm{mM}$-dbcAMP to TCM containing $0.5 \mu \mathrm{M}$-testosterone on the incidence of maturation of intact liberated oocytes was assessed. Oocytes were collected from ovaries in modified BMOC, containing dextran T-70, 0.5 $\mu \mathrm{M}$-testosterone and the same concentration of dbcAMP in which they were cultured.

Experiment 3. This series of experiments was performed to determine whether it was necessary to harvest oocytes in medium supplemented with those components present in the medium in which they were to be cultured. Three groups of oocytes were used, two harvested in TCM and one harvested in TCM supplemented with $0.5 \mu \mathrm{M}$-testosterone and $1 \mathrm{mM}$-dbcAMP. Oocytes in one of the groups collected in TCM were subsequently washed and cultured in the supplemented medium. Those in the other groups were washed and cultured in media containing the same supplements as in the collection media.

Experiment 4. The independent effects of dbcAMP and testosterone on the spontaneous maturation of the intact, liberated oocyte were determined. Oocytes were cultured in medium containing no testosterone or dbcAMP, or containing $1 \mathrm{mM}$-dbcAMP, $0.5 \mu \mathrm{M}$-testosterone or 1 mM-dbcAMP + 0.5 $\mu \mathrm{M}$-testosterone.

Experiment 5. This series was carried out to determine whether the effect on maturation 
induced by dbcAMP with testosterone was reversible. Groups of oocytes were cultured for 24 and $48 \mathrm{~h}$ in unsupplemented medium (control) or medium containing testosterone with dbcAMP (experimental). An additional group was cultured for $24 \mathrm{~h}$ in experimental medium and then transferred to control medium for a further $24 \mathrm{~h}$. After culture for $24 \mathrm{~h}$, those oocytes to be cultured for an additional $24 \mathrm{~h}$ were washed successively in three dishes of the appropriate medium before their return to culture.

Experiment 6 . The effect of testosterone $+\mathrm{dbcAMP}$ on the spontaneous maturation of intact and denuded oocytes and denuded oocytes co-cultured with free cumulus cells was determined to provide information about the possible role of the cumulus cell in mediating the action of testosterone and dbcAMP on maturation.

Experiment 7. The independent effects of testosterone and dbcAMP on the spontaneous maturation of denuded oocytes were determined. Denuded oocytes were cultured in the same media as described for intact oocytes in Exp. 4.

\section{Results}

\section{Experiment 1}

In 5 experiments, $71 \%$ of 110 intact oocytes had matured after $24 \mathrm{~h}$ in vitro. In 4 of the experiments, an average of $5 \%$ granulosa cells in each cumulus mass were stained with trypan blue, indicating a very high incidence of viability for these somatic cells in the culture system. Approximately $90 \%$ of the stained cells had migrated from the cumulus oophorus.

Table 1. The effect of testosterone and dibutyryl cAMP on the maturation of liberated, intact pig oocytes

\begin{tabular}{cccc}
\hline \multirow{2}{*}{$\begin{array}{c}\text { No. of } \\
\text { oocytes }\end{array}$} & \multicolumn{2}{c}{ Supplement } & $\begin{array}{c}\text { Mean \% of oocytes } \\
\text { that matured from } \\
\text { diakinesis to MII }\end{array}$ \\
\cline { 2 - 3 } & Testosterone $(\mu \mathrm{M})$ & dbcAMP $(\mathrm{mM})$ & \\
110 & 0 & 0 & $71 \cdot 2^{\mathrm{a}}(62 \cdot 8-79 \cdot 4)$ \\
114 & $0 \cdot 50$ & 0 & $58 \cdot 7^{\mathrm{b}}(51 \cdot 3-65 \cdot 8)$ \\
120 & $0 \cdot 50$ & $0 \cdot 01$ & $33 \cdot 0^{\mathrm{c}}(18 \cdot 2-49 \cdot 8)$ \\
98 & 0.50 & 0.10 & $36.9^{\mathrm{c}}(23 \cdot 2-51 \cdot 8)$ \\
111 & 0.50 & 1.00 & $13 \cdot 8^{\mathrm{d}}(5 \cdot 7-24 \cdot 7)$ \\
\hline
\end{tabular}

Figures in parentheses are the $95 \%$ confidence intervals for the means. Groups with different superscripts are significantly different, $\alpha=0.05$.

\section{Experiment 2}

All three concentrations of dbcAMP caused a significant decrease in oocyte maturation compared with maturation of oocytes cultured in TCM supplemented with testosterone alone. The most marked inhibitory effect was exerted by $1 \mathrm{~mm}$-dbcAMP (14\% matured, Table 1 ) and no significant difference in maturation was observed between groups of oocytes cultured in the two lower concentrations ( 33 and $37 \%$ matured).

\section{Experiment 3}

The inhibition of maturation exerted by dbcAMP and testosterone was not significantly affected by the collection of oocytes in unsupplemented medium before culture in the 'inhibitory' medium (Table 2). In subsequent experiments, therefore, all oocytes were collected in control, unsupplemented medium. 
Table 2. The effect on the inhibition of maturation by testosterone $(0.5 \mu \mathrm{M})$ and dbcAMP $(1 \mathrm{~mm})$ of collecting intact pig oocytes in control medium

\begin{tabular}{|c|c|c|c|}
\hline $\begin{array}{l}\text { No. of } \\
\text { oocytes }\end{array}$ & $\begin{array}{l}\text { Collection } \\
\text { medium }\end{array}$ & $\begin{array}{l}\text { Culture } \\
\text { medium }\end{array}$ & $\begin{array}{l}\text { Mean } \% \text { of oocytes } \\
\text { that matured from } \\
\text { diakinesis to MII }\end{array}$ \\
\hline 35 & Control* & Control* & $78.0^{\mathrm{a}}(66 \cdot 3-87 \cdot 7)$ \\
\hline 53 & Control ${ }^{*}$ & $T+$ dbcAMP & $14.5^{b}(1.6-37.0)$ \\
\hline 53 & $T+d b c A M P$ & $T+$ dbcAMP & $18.2^{\mathrm{b}} \quad(2.8-42.7)$ \\
\hline
\end{tabular}

* Unsupplemented medium containing $1 \mu$ ethanol $/ \mathrm{ml}$.

Figures in parentheses are the $95 \%$ confidence intervals for the means.

Groups with different superscripts are significantly different, $\alpha=0.05$.

\section{Experiment 4}

The addition of dbcAMP or testosterone to the culture medium caused a significant inhibition of maturation ( 58 and $56 \%$ matured, respectively) compared with the maturation of oocytes cultured in unsupplemented TCM (74\% matured). The inhibition exerted by either compound independently, however, was not nearly as marked as when both compounds were present in the medium (19\% matured; Table 3$)$. There was no statistical difference in the inhibition exerted by dbcAMP as compared with that exerted by testosterone, although there was a significant reduction in the number of oocytes that completed maturation when oocytes were cultured in medium containing either compound separately or in combination. Furthermore, there were significantly fewer degenerate GVs in inhibited oocytes cultured in medium supplemented with testosterone + dbcAMP than in immature oocytes in any of the other groups. It was consistently observed that the cumuli of oocytes exposed to testosterone + dbcAMP remained as compact cell masses adhering to the oocytes whereas oocytes maintained in control medium or medium supplemented with testosterone or dbcAMP separately changed into fibroblast-like, sparsely granulated cells that attached to the surface of the slide.

Table 3. The effect of testosterone $(0.5 \mu \mathrm{M})$ and dbcAMP $(1 \mathrm{mM})$ on the maturation of liberated, intact pig oocytes

Mean \% of oocytes which matured

\begin{tabular}{|c|c|c|c|c|}
\hline \multirow[b]{2}{*}{$\begin{array}{l}\text { No. of } \\
\text { oocytes }\end{array}$} & \multirow[b]{2}{*}{$\begin{array}{c}\text { Medium } \\
\text { supplement }\end{array}$} & \multicolumn{2}{|c|}{ Mean \% of oocytes which matured } & \multirow[b]{2}{*}{$\begin{array}{c}\text { Mean } \% \text { of immature oocytes } \\
\text { with degenerate GVs }\end{array}$} \\
\hline & & $\begin{array}{c}\text { Category I } \dagger \\
\text { (diakinesis to MII) }\end{array}$ & $\begin{array}{c}\text { Category II } \\
\text { (anaphase I to MII) }\end{array}$ & \\
\hline 74 & None* & $74 \cdot 0^{2}(63 \cdot 8-83 \cdot 0)$ & $(34 \cdot 7-62 \cdot 6)$ & $41 \cdot 4^{a}(20 \cdot 7-63 \cdot 8)$ \\
\hline 66 & dbcAMP & $58 \cdot 2^{b}(47 \cdot 9-68 \cdot 2)$ & $23 \cdot 1^{\mathrm{b}} \quad(19 \cdot 5-26 \cdot 8)$ & $39 \cdot 2^{\mathrm{a}}(23 \cdot 1-56 \cdot 7)$ \\
\hline 79 & Testosterone & $56.9^{b}(47.9-65.6)$ & $36 \cdot 6^{\mathrm{a}, \mathrm{b}}(10 \cdot 4-68 \cdot 3)$ & $40 \cdot 8^{\mathrm{a}}(14.8-70 \cdot 0)$ \\
\hline 80 & dbcAMP + testosterone & $19 \cdot 1^{\mathrm{c}}(12 \cdot 1-27 \cdot 1)$ & $19 \cdot 6^{b} \quad(6 \cdot 8-36 \cdot 9)$ & $16 \cdot 8^{\mathrm{b}}(10 \cdot 9-23 \cdot 8)$ \\
\hline
\end{tabular}

\footnotetext{
* Medium containing $1 \mu \mathrm{l}$ ethanol $/ \mathrm{ml}$.

$+\%$ of oocytes cultured.

$\ddagger \%$ of oocytes in Category I.

Figures in parentheses are the $95 \%$ confidence intervals for the means.

Groups with different superscripts are significantly different, $\alpha=\mathbf{0 . 0 5}$.
}

\section{Experiment 5}

The inhibitory effect on maturation exerted by dbcAMP and testosterone was reversible. Statistically different subsets of experimental groups were observed (Table 4). Oocytes cultured for $24 \mathrm{~h}$ in 'inhibitory' medium matured at control levels (Group A) after being transferred to 
control medium for an additional $24 \mathrm{~h}$ (Group E; 54\% matured). Oocytes which remained in 'inhibitory' medium for 24 (Group B; 22\% matured) or 48 (Group D; 22\% matured) h were inhibited in comparison to oocytes which were cultured for 24 (Group A) or 48 (Group C) h in control medium (69 and $77 \%$ matured, respectively).

Table 4. Maturation of liberated, intact pig oocytes inhibited by testosterone $(\mathrm{T}, 0.5 \mu \mathrm{M})$ and dibutryl cAMP (1 mM)

\begin{tabular}{|c|c|c|c|c|c|}
\hline \multirow[b]{2}{*}{ Group } & \multirow[b]{2}{*}{$\begin{array}{l}\text { No. of } \\
\text { oocytes }\end{array}$} & \multirow[b]{2}{*}{$\begin{array}{c}\text { Medium } \\
\text { supplement }\end{array}$} & \multirow[b]{2}{*}{$\begin{array}{l}\text { Culture } \\
\text { time (h) }\end{array}$} & \multicolumn{2}{|c|}{ Mean $\%$ of oocytes which matured } \\
\hline & & & & $\begin{array}{c}\text { Category I† } \\
\text { (diakinesis to MII) }\end{array}$ & $\begin{array}{c}\text { Category II } \\
\text { (anaphase I to MII) }\end{array}$ \\
\hline A & 64 & None* & 24 & $69 \cdot 0^{\mathrm{a} \cdot \mathrm{b}}(54 \cdot 5-81 \cdot 7)$ & $77 \cdot 2^{\mathrm{a} \cdot \mathrm{b}}(66 \cdot 6-86 \cdot 2)$ \\
\hline $\mathrm{B}$ & 61 & $\mathrm{~T}+\mathrm{dbcAMP}$ & 24 & $21 \cdot 5^{\mathrm{c}} \quad(5 \cdot 9-43 \cdot 3)$ & $66 \cdot 8^{\circ} \quad(43 \cdot 7-86 \cdot 2)$ \\
\hline C & 55 & None* & 48 & $76 \cdot 5^{\mathrm{a}} \quad(65 \cdot 0-90 \cdot 0)$ & $92 \cdot 0^{\mathrm{b}} \quad(86 \cdot 3-96 \cdot 3)$ \\
\hline $\mathrm{D}$ & 65 & $\mathrm{~T}+\mathrm{dbcAMP}$ & 48 & $(5 \cdot 0-47.5)$ & $86 \cdot 7^{\mathrm{a}, \mathrm{b}}(77 \cdot 0-96 \cdot 9)$ \\
\hline $\mathrm{E}$ & 65 & $\begin{array}{l}\mathrm{T}+\mathrm{dbcAMP} \\
\text { None }^{*}\end{array}$ & $\begin{array}{l}24 \\
24\end{array}$ & $54 \cdot 4^{b} \quad(41 \cdot 6-66 \cdot 8)$ & $77 \cdot 5^{\mathrm{a}, \mathrm{b}}(48 \cdot 9-96 \cdot 4)$ \\
\hline
\end{tabular}

\footnotetext{
* Medium containing $1 \mu \mathrm{l}$ ethanol $/ \mathrm{ml}$.

$\dagger \%$ of oocytes cultured.

$\ddagger \%$ of oocytes in Category $I$.

Figures in parentheses are the $95 \%$ confidence intervals for the means.

Groups with different superscripts are significantly different, $\alpha=0.05$.
}

\section{Experiment 6}

There were no significant differences in the maturation of intact oocytes cultured in control medium compared with that of denuded oocytes cultured with or without cumulus cells in this medium (Table 5). Similarly, intact oocytes cultured in the 'inhibitory' medium were inhibited to

Table 5. The effect of testosterone ( $T, 0.5 \mu \mathrm{M})$ and dbcAMP ( $1 \mathrm{~mm})$ on the maturation of liberated intact and denuded pig oocytes, and denuded oocytes co-cultured with cumulus cells

\begin{tabular}{|c|c|c|c|c|c|c|}
\hline \multirow[b]{2}{*}{$\begin{array}{l}\text { Type of } \\
\text { oocyte }\end{array}$} & \multirow[b]{2}{*}{$\begin{array}{l}\text { Medium } \\
\text { supplement }\end{array}$} & \multirow[b]{2}{*}{$\begin{array}{c}\text { No. of } \\
\text { oocytes }\end{array}$} & \multicolumn{3}{|c|}{ Mean $\%$ of oocytes which matured } & \multirow[b]{2}{*}{$\begin{array}{c}\text { Mean \% } \\
\text { with } \\
\text { degenerate GV }\end{array}$} \\
\hline & & & $\begin{array}{l}\text { Category I } \dagger \\
\text { (diakinesis } \\
\text { to MII) }\end{array}$ & $\begin{array}{c}\text { Category II } \ddagger \\
\text { (anaphase I } \\
\text { to MII) }\end{array}$ & $\begin{array}{l}\text { Category III§ } \\
\text { (anaphase I } \\
\text { to MII) }\end{array}$ & \\
\hline Intact & None* & 100 & $\begin{array}{c}73 \cdot 5^{\mathrm{a}, \mathrm{A}} \\
(68 \cdot 3-78 \cdot 5)\end{array}$ & $\begin{array}{c}62 \cdot 9^{c} \\
(48 \cdot 8-76 \cdot 0)\end{array}$ & $\begin{array}{c}64 \cdot 7^{\mathrm{d}} \\
(45 \cdot 57-81 \cdot 5)\end{array}$ & $\begin{array}{c}26 \cdot 8^{\mathrm{A}} \\
(11 \cdot 8-45 \cdot 1)\end{array}$ \\
\hline Denuded & None* & 88 & $\begin{array}{c}64 \cdot 4^{\mathrm{a}, \mathrm{A}} \\
(53 \cdot 1-75 \cdot 0)\end{array}$ & $\begin{array}{c}66 \cdot 6^{c} \\
(42 \cdot 9-86 \cdot 6)\end{array}$ & $\begin{array}{c}59 \cdot 2^{d} \\
(44.9-72 \cdot 8)\end{array}$ & $\begin{array}{c}33 \cdot 2^{\mathrm{A}} \\
(20 \cdot 5-47 \cdot 3)\end{array}$ \\
\hline $\begin{array}{l}\text { Denuded }+ \\
\text { cumulus cells }\end{array}$ & None* & 94 & $\begin{array}{c}76 \cdot 8^{\mathrm{a}, \mathrm{A}} \\
(60 \cdot 3-77 \cdot 2)\end{array}$ & $\begin{array}{c}62 \cdot 7^{\mathrm{c}} \\
(41 \cdot 2-81.9)\end{array}$ & $\begin{array}{c}65 \cdot 0^{d} \\
(41.9-84.9)\end{array}$ & $\begin{array}{c}49 \cdot 3^{\mathrm{A}} \\
(28 \cdot 2-70 \cdot 5)\end{array}$ \\
\hline Intact & $\mathrm{T}+\mathrm{dbcAMP}$ & 99 & $\begin{array}{c}16 \cdot 6^{\mathrm{b}, \mathrm{B}} \\
(8 \cdot 6-26 \cdot 6)\end{array}$ & $\begin{array}{c}61 \cdot 7^{\mathrm{c}} \\
(32 \cdot 1-87 \cdot 2)\end{array}$ & $\begin{array}{c}41 \cdot 3^{\mathrm{d}} \\
(14 \cdot 0-72 \cdot 0)\end{array}$ & $\begin{array}{c}10 \cdot 2^{\mathrm{B}} \\
(4 \cdot 0-43 \cdot 1)\end{array}$ \\
\hline Denuded & $\mathrm{T}+\mathrm{dbcAMP}$ & 81 & $\begin{array}{c}23 \cdot 7^{\mathrm{b}, \mathrm{B}} \\
(13 \cdot 2-36 \cdot 0)\end{array}$ & $\begin{array}{c}64 \cdot 5^{\mathrm{c}} \\
(39 \cdot 6-85 \cdot 7)\end{array}$ & $\begin{array}{c}54 \cdot 0^{\mathrm{d}} \\
(25 \cdot 4-81 \cdot 0)\end{array}$ & $\begin{array}{c}28 \cdot 6^{\mathrm{c}} \\
(16 \cdot 1-43 \cdot 1)\end{array}$ \\
\hline $\begin{array}{l}\text { Denuded }+ \\
\text { cumulus cells }\end{array}$ & $T+d b c A M P$ & 99 & $\begin{array}{c}22 \cdot 2^{\mathrm{b}, \mathrm{B}} \\
(10 \cdot 4-36 \cdot 9)\end{array}$ & $\begin{array}{c}49 \cdot 9^{c} \\
(29 \cdot 0-70 \cdot 8)\end{array}$ & $\begin{array}{c}67 \cdot 8^{d} \\
(39 \cdot 7-90 \cdot 3)\end{array}$ & $\begin{array}{c}18 \cdot 6^{\mathrm{B} . \mathrm{C}} \\
(6 \cdot 5-35 \cdot 5)\end{array}$ \\
\hline
\end{tabular}

* Medium containing I $\mu \mathrm{l}$ ethanol/ml.

$\dagger \%$ oocytes cultured.

$\ddagger \%$ of oocytes in Category $\mathrm{I}$.

$\S \%$ of oocytes in Category II (excludes diploid metaphase II oocytes).

Figures in parentheses are the $95 \%$ confidence limits for the means.

Letters for groups represent significantly different statistical subsets $(\alpha=0.05)$ when comparing all groups with each other $(a, b, c, d)$ and when comparing the groups of oocytes cultured in control medium or medium supplemented with $\mathrm{T}+\mathrm{dbcAMP}(\mathrm{A}, \mathrm{B}, \mathrm{C})$. 
the same extent as denuded oocytes or denuded oocytes co-cultured with free cumulus cells in this medium. Comparison of the maturation of each group of oocytes cultured in control medium with that of each group maintained in the 'inhibitory' medium revealed that a significant inhibition of maturation was obtained in each group of oocytes maintained in 'inhibitory' medium. In addition, there were no significant differences detected in the proportion of matured oocytes that reached anaphase I to metaphase II among any of the groups (Category II) or in the incidence of abnormality in the oocytes (Category III). There were no significant differences in the proportion of degenerate GVs amongst any of the groups of oocytes cultured in control medium. Amongst the oocytes cultured in medium supplemented with testosterone + dbcAMP, there were significantly fewer degenerate GVs in the intact oocytes than in the denuded oocytes, but no significant difference in the number of degenerate GVs of denuded oocytes co-cultured with free cumulus cells as compared with that of intact or denuded oocytes. Collectively, there were significantly fewer degenerate GVs in inhibited oocytes cultured in medium supplemented with testosterone + dbcAMP than in immature oocytes cultured in control medium (19 compared with $36 \%$; Table 6).

Table 6. The effect of testosterone $(0.5 \mu \mathrm{M})$ and dbcAMP (1 mM) on pig oocyte germinal vesicles $(\mathrm{GV})$

\begin{tabular}{lccc}
\hline \multicolumn{1}{c}{$\begin{array}{c}\text { Medium } \\
\text { supplement }\end{array}$} & $\begin{array}{c}\text { No. of } \\
\text { oocytes }\end{array}$ & $\begin{array}{c}\text { No. at } \\
\text { GV stage (\%) }\end{array}$ & $\begin{array}{c}\text { Mean \% with } \\
\text { degenerate GVs }\end{array}$ \\
\hline None $^{*}$ & 292 & $92(32)$ & $36 \cdot 2^{\mathrm{a}}(26 \cdot 8-46 \cdot 2)$ \\
Testosterone + dbcAMP & 279 & $221(79)$ & $18 \cdot 6^{\mathrm{b}}(12 \cdot 2-25 \cdot 8)$ \\
\hline
\end{tabular}

* Medium containing $1 \mu \mathrm{l}$ ethanol $/ \mathrm{ml}$.

Figures in parentheses are the $95 \%$ confidence intervals for the means.

Groups with different superscripts are significantly different, $\alpha=0.05$.

\section{Experiment 7}

Maturation of denuded oocytes cultured in medium supplemented with dbcAMP or with dbcAMP + testosterone was significantly inhibited (11 and 15\% matured, respectively), relative to that of oocytes cultured in unsupplemented medium (68\% matured; Table 7). Testosterone alone had no effect on maturation.

Statistical analysis of the effect of dbcAMP, testosterone, or dbcAMP + testosterone revealed that there was no significant difference in the inhibition exerted by dbcAMP on denuded oocytes and that exerted by dbcAMP + testosterone on denuded or intact oocytes. In addition, compared with controls, there were no significant differences in maturation of either type of oocyte in medium supplemented with testosterone or of intact oocytes in medium supplemented with dbcAMP.

Table 7. The effect of testosterone $(0.5 \mu \mathrm{M})$ and dbcAMP ( $1 \mathrm{mM})$ on the maturation of liberated, denuded pig oocytes

\begin{tabular}{|c|c|c|c|c|}
\hline \multirow[b]{2}{*}{$\begin{array}{l}\text { No. of } \\
\text { oocytes }\end{array}$} & \multirow[b]{2}{*}{$\begin{array}{l}\text { Medium } \\
\text { supplement }\end{array}$} & \multicolumn{2}{|c|}{ Mean $\%$ of oocytes which matured } & \multirow{2}{*}{$\begin{array}{c}\text { Mean } \% \text { of immature } \\
\text { oocytes with } \\
\text { degenerate GVs }\end{array}$} \\
\hline & & $\begin{array}{c}\text { Category I } \dagger \\
\text { (diakinesis to MII) }\end{array}$ & $\begin{array}{c}\text { Category II } \ddagger \\
\text { (anaphase I to MII) }\end{array}$ & \\
\hline 56 & None* & $68 \cdot 0^{a}(55 \cdot 2-79 \cdot 5)$ & $71 \cdot 6^{a}(27.6-98.9)$ & $(2 \cdot 6-87 \cdot 8)$ \\
\hline 66 & dbcAMP & $11.4^{b}(0.0-39 \cdot 5)$ & $41 \cdot 3^{\mathrm{a}}(10 \cdot 1-77 \cdot 3)$ & $(2 \cdot 0-26 \cdot 2)$ \\
\hline 60 & Testosterone & $69 \cdot 1^{\mathrm{a}}(47 \cdot 2-87 \cdot 2)$ & $62 \cdot 7^{a}(45 \cdot 0-78.9)$ & $33.8^{\mathrm{a}, \mathrm{b}}(16 \cdot 0-30 \cdot 0)$ \\
\hline 59 & dbcAMP + testosterone & $14 \cdot 7^{b}(5 \cdot 9-26 \cdot 4)$ & $32 \cdot 3^{\mathrm{a}} \quad(0 \cdot 0-87 \cdot 0)$ & $22 \cdot 0^{\mathrm{a}, \mathrm{b}}(14 \cdot 9-30 \cdot 0)$ \\
\hline
\end{tabular}

* Medium containing $1 \mu \mathrm{l}$ ethanol $/ \mathrm{ml}$.

$\dagger \%$ of oocytes cultured.

$\ddagger \%$ of oocytes in Category $I$.

Figures in parentheses are the $95 \%$ confidence intervals for the means.

Groups with different superscripts are significantly different, $\alpha=0.05$. 


\section{Discussion}

The documented systems in which oocyte maturation has been inhibited have involved culture of oocytes under two types of conditions. Either liberated oocytes have been co-cultured with membrana granulosa cells or they have been maintained in medium containing a variety of biological compounds. Although marked inhibition of maturation has been reported for porcine (Tsafriri \& Channing, 1975) and rat (Tsafriri, 1979) oocytes by co-cultured membrana granulosa cells, such an effect has not been demonstrated by others for mouse (Nekola \& Smith, 1974) or pig (Jagiello et al., 1977; Rice \& McGaughey, 1980) oocytes. In addition, when liberated oocytes have been exposed to biological compounds, in no case has a physiological concentration of any 'inhibitor' been used that inhibited more than $50 \%$ of control oocytes, whether the 'inhibitor' was oocyte maturation inhibitor (OMI) (Stone et al., 1978; Hillensjö, Channing, Pomerantz \& Schwartz-Kripner, 1979) or oestradiol (McGaughey, 1977a; Richter \& McGaughey, 1979). Since the present results indicate that a very high incidence of reversible inhibition can be achieved with a physiological concentration of testosterone and a high concentration of dbcAMP, the system provides an alternative, and potentially very useful, system with which to investigate the regulatory mechanisms of oocyte maturation.

The concentration of testosterone used in this study $(0.5 \mu \mathrm{M})$ was selected since rat (Dorrington et al., 1975) and human (Moon, Tsang, Simpson \& Armstrong, 1978) granulosa cells in a cell suspension system, and intact ovaries of the rat (Moon, Dorrington \& Armstrong, 1975 ) in an organ culture system, synthesize maximal amounts of oestradiol at this concentration of androgen in the presence of FSH $(0.25 \mu \mathrm{g} / \mathrm{ml})$. In addition, the selected androgen concentration was of the same order of magnitude as is reported to be present in the follicular fluid of sows (Eiler \& Nalbandov, 1977), women (McNatty, 1978; McNatty \& Baird, 1978) and mares (Short, 1960), although approximately 10 times greater than that measured in cow (Short, 1962) or estimated in mouse (Tyler, Moore-Smith \& Biggers, 1980), follicular fluid. The concentration range for dbcAMP was selected since both rabbit (Erickson \& Ryan, 1975) and rat (Dorrington \& Armstrong, 1975) granulosa cells exhibit an increased aromatization capacity at concentrations of 1 and $0.1 \mathrm{mM}$-dbcAMP, respectively.

The maturation of a very high proportion of intact oocytes was inhibited in medium containing testosterone and dbcAMP. Nevertheless, some oocytes escaped this inhibitory action. The possibility exists that some of the matured oocytes had undergone maturation in vivo. It is known that oocytes of some atretic antral follicles in the human ovary undergo maturation within the follicle before degenerating (Himelstein-Braw, Byskov, Peters \& Faber, 1976), although a cytogenetic study has indicated that only $0.2 \%$ of selected, healthy pig oocytes exhibit chromosomal condensation at the time of oocyte collection (McGaughey et al., 1979). Since approximately $15 \%$ of oocytes had matured during culture in the inhibitory system, it is unlikely that maturation of all these matured oocytes can be accounted for by atresia.

Our observation that pig oocytes do not undergo an immediate irreversible release from inhibition upon removal from the follicle is of interest. Germinal vesicle breakdown (GVBD) in the pig oocyte does not occur until the oocyte has been released from the follicle for at least $5 \mathrm{~h}$ (unpublished observation), but the processes involved in preparation for this event may occur considerably earlier. The results of Exp. 3, however, indicate that these processes do not occur, irreversibly, within $2 \frac{1}{2} \mathrm{~h}$ of removal of the oocyte from the follicle (Table 2). It remains to be seen whether the liberated pig oocyte is susceptible to inhibition for the total period before overt GVBD, as has been demonstrated for inhibition of mouse oocytes with dbcAMP (Cho, Stern \& Biggers, 1974).

The mechanism(s) by which testosterone and dbcAMP act to inhibit oocyte maturation remains undetermined. Since, however, oestradiol has been shown to inhibit porcine oocyte maturation reversibly (McGaughey, 1977a; Richter \& McGaughey, 1979) and since granulosa cells of many species (pig: Bjersing \& Carstensen, 1967; Anderson et al., 1979; mare: 
Channing, 1969; cow: Lacroix et al., 1974; rabbit: Erickson \& Ryan, 1975; sheep: Moor, 1977; rat: Fortune \& Armstrong, 1978) aromatize androgens to oestrogen, the possibility exists that oestradiol of granulosa cell origin mediated the inhibitory action of testosterone and dbcAMP on the intact oocyte. Although the maturation of denuded oocytes was also inhibited by testosterone and dbcAMP, our results show that this inhibition was due to a direct action of the CAMP derivative on the oocyte, with testosterone playing a purely passive role. The addition of only dbcAMP to the medium resulted in a significant inhibition of maturation compared with the control, and this inhibition was not significantly different from that resulting from dbcAMP + testosterone. Further, testosterone exerted no independent inhibitory action on denuded oocytes (Table 7). These data suggest, therefore, that dbcAMP acted directly at the level of the denuded oocyte to inhibit maturation. This conclusion is consistent with the observation that dbcAMP inhibits the maturation of denuded mouse oocytes (Cho et al., 1974; Stern \& Wassarman, 1974; Wassarman \& Turner, 1976).

In contrast to the independent actions of the two compounds on the denuded oocyte, testosterone, in addition to dbcAMP, exerted a significant inhibitory effect on the maturation of intact oocytes (Table 3). Neither of the independent actions, however, was as marked as when both compounds were present together in the medium, and a synergistic relationship between testosterone and dbcAMP was indicated. The observed effect of testosterone on maturation was similar to that reported by Richter \& McGaughey (1979), although the concentrations of steroid used in the two systems were quite different $(0.5$ and $35 \mu \mathrm{M}$, respectively). It is possible that the inhibition induced by testosterone alone was due to a low residual aromatase activity of the granulosa cells in the absence of dbcAMP. Granulosa cells in several different preparations can aromatize testosterone without added FSH (Aksel, Schomberg, Tyrey \& Hammond, 1976; Anderson et al., 1979; Schomberg, 1979). Alternatively, 'residual' FSH-bound receptors, known to exist in the granulosa cell (Moon et al., 1978), could increase intracellular cAMP, resulting in aromatization of testosterone.

The mechanism( $\mathrm{s}$ ) by which dbcAMP independently reduced the incidence of maturation of intact oocytes is not clear. It is unlikely that the cyclic nucleotide, in the absence of exogenous testosterone, stimulated oestradiol biosynthesis because neither dbcAMP (Erickson \& Ryan, 1975; Dorrington \& Armstrong, 1975) nor FSH (Dorrington et al., 1975; Fortune \& Armstrong, 1978; Anderson et al., 1979) have been shown to stimulate granulosa cell oestradiol synthesis in the absence of substrate.

In addition to aromatization of androgen, several studies demonstrate androgen-stimulated progesterone production by isolated granulosa cells in vitro (Schomberg, Stouffer \& Tyrey, 1976; Armstrong \& Dorrington, 1976; Lucky, Schreiber, Hillier, Schulman \& Ross, 1977). The possibility exists, therefore, that both progesterone and oestradiol are synthesized by cumulus cells exposed to testosterone and dbcAMP but that oestradiol is synthesized to a greater extent, resulting in a ratio of oestradiol :progesterone which approximates that in the immature follicle (Thibault, 1977; Gérard et al., 1979) and favours inhibition of maturation (McGaughey, 1977a; Moore-Smith, Tyler \& Erickson, 1978). Indeed, oestradiol has been shown to inhibit FSHstimulated progesterone synthesis by porcine granulosa cells (Schomberg et al., 1976; Hillier, Knazek \& Ross, 1977; Thanki \& Channing, 1978; Haney \& Schomberg, 1978). In this context, it is of significance that oocyte maturation inhibitor (OMI) inhibits progesterone secretion by cumulus and membrana granulosa cells (Hillensjö et al., 1979). In addition, the typical cumulus monolayer formation which accompanies oocyte maturation in vitro (Hillensjö et al., 1979) was prevented by partly purified OMI. The cumulus masses of inhibited oocytes maintained in testosterone and dbcAMP in the present study likewise do not exhibit a monolayer outgrowth. There is an indication, therefore, that testosterone and dbcAMP affect the morphological differentiation of the cumulus cell in a manner similar to that reported for OMI.

The demonstrated inhibitory effect of testosterone and dbcAMP on the intact oocyte was reversible (Table 4), a result supported by the observation that fewer GVs were degenerate in 
oocytes cultured in the inhibitory system than in oocytes maintained in control, unsupplemented medium (Table 6). Our results do not, therefore, support the hypothesis that androgens act locally to produce follicular atresia (Payne \& Runser, 1958; Speroff \& van Wielle, 1971; Louvet, Harman, Schreiber \& Ross, 1975), but indicate that androgens may play an important regulatory role in granulosa cell development, as suggested by others (Moor, Hay \& Seamark, 1975; Schomberg et al., 1976; Nimrod \& Lindner, 1976; Anderson et al., 1979; Tyler et al., 1980).

The results of this study indicate that the inhibitory action exerted by testosterone + dbcAMP is mediated by cumulus cells. Inhibition could be accomplished by oestradiol, or by a protein(s), the synthesis of which is induced by testosterone, oestradiol or dbcAMP, or any interaction among these compounds. Alternatively, testosterone and dbcAMP could act to suppress the synthesis and/or release of inductor molecules produced by the somatic cells, as suggested by Schuetz (1979). Investigations are in progress to determine which of these mechanisms are involved.

We thank Kathy Eastman for technical assistance, Becky Payne for typing the manuscript, and Cudahy Foods of Phoenix, Arizona for supplying the pig reproductive tracts. This study was supported by Grant HD06532 and a grant from the Whitehall Foundation.

\section{References}

Aksel, S., Schomberg, D.W., Tyrey, L. \& Hammond, C.B. (1976) Vasomotor symptoms, serum estrogens, and gonadotropin levels in surgical menopause. $\mathrm{Am}$. J. Obstet. Gynec. 126, 165-169.

Anderson, L.D., Schaerf, F.W. \& Channing, C.P. (1979) Effects of follicular development on the ability of cultured granulosa cells to convert androgen to estrogen. In Ovarian Follicular and Corpus Luteum Function, pp. 187-195. Eds C. P. Channing, J. Marsh \& W. Sadler. Plenum Press, New York.

Armstrong, D.T. \& Dorrington, J.H. (1976) Androgens augment FSH-induced progesterone secretion by cultured rat granulosa cells. Endocrinology 99, $1411-1414$.

Armstrong, D.T., Goff, A.F. \& Dorrington, J.H. (1979) Regulation of follicular estrogen biosynthesis. In Ovarian Follicular Development and Function, pp. 169-181. Eds A. R. Midgley \& W. A. Sadler. Raven Press, New York.

Bjersing, L. \& Cartensen, H. (1967) Biosynthesis of steroids by granulosa cells of the porcine ovary in vitro. J. Reprod. Fert. 14, 101-111.

Brinster, R.L. (1971) Measuring embryonic enzyme activities. In Methods in Mammalian Embryology, pp. 215-227. Ed. J. C. Daniel, Jr. W. H. Freeman \& Co., San Francisco.

Channing, C.P. (1969) Tissue culture of equine ovarian cell types: effect of gonadotropins and stage of cycle on steroidogenesis. J. Endocr. 43, 415-425.

Cho, W.K., Stern, S. \& Biggers, J.D. (1974) Inhibitory effect of dibutyryl cAMP on mouse oocyte maturation in vitro. J. exp. Zool. 187, 383-386.

Dekel, N. \& Beers, W.H. (1978) Rat oocyte maturation in vitro; relief of cyclic AMP inhibition by gonadotropins. Proc. natn. Acad. Sci. U.S.A. 75, 43694373 .
Donahue, R.P. (1972) The relation of oocyte maturation to ovulation in mammals. In Oogenesis, pp. 413-438. Eds J. D. Biggers \& A. W. Schuetz. University Park Press, Baltimore.

Dorrington, J.H. \& Armstrong, D.T. (1975) Folliclestimulating hormone stimulates estradiol-17 $\beta$ synthesis in cultured Sertoli cells. Proc. natn. Acad. Sci. U.S.A. 72, 2677-2681.

Dorrington, J.H., Moon, Y.S. \& Armstrong, D.T. (1975) Estradiol-17 $\beta$ biosynthesis in cultured granulosa cells from hypophysectomized immature rats, stimulation by follicle stimulating hormone. Endocrinology 97, 1328-1331.

Duncan, D.B. (1955) Multiple range and multiple ' $F$ ' tests. Biometrics $I I, 1-42$.

Eiler, H. \& Nalbandov, A.V. (1977) Sex steroids in follicular fluid and blood plasma during the estrous cycle of pigs. Endocrinology 100, 331-338.

Erickson, G.F. \& Ryan, K.J. (1975) The effect of LH/FSH, dibutyryl cAMP, and prostaglandins on the production of estrogens by rabbit granulosa cells in vitro. Endocrinology 97, 108-113.

Fortune, J.E. \& Armstrong, D.T. (1978) Hormonal control of $17 \beta$-estradiol biosynthesis in proestrous rat follicles: estradiol production by isolated theca vs. granulosa. Endocrinology 102, 227-235.

Gérard, Y., Ménézo, Y., Rombauts, P., Szöllösi, D. \& Thibault, C. (1979) In vitro studies of oocyte maturation and follicular metabolism in the pig. Annls Biol. anim. Biochim. Biophys. 19, 15211535.

Haney, A.F. \& Schomberg, D.W. (1978) Steroidal modulation of progesterone secretion by granulosa cells from large porcine follicles: a role for androgens and estrogens in controlling steroidogenesis. Biol. Reprod. 19, 242-248. 
Hillensjö, T., Hamberger, L. \& Ahrén, K. (1975) Respiratory activity of oocytes isolated from ovarian follicles of the rat. Acta endocr., Copenh. 78, 751-759.

Hillensjö, T., Channing, C.P., Pomerantz, S.H. \& Schwartz-Kripner, A. (1979) Intrafollicular control of oocyte maturation in the pig. In vitro $15,32-39$.

Hillier, S.G., Knazek, R.A. \& Ross, G.T. (1977) Androgenic stimulation of progesterone production by granulosa cells from preantral ovarian follicles: further in vitro studies using replicate cultures. Endocrinology 100, 1539-1549.

Himelstein-Braw, R., Byskov, A.G., Peters, H. \& Faber, M. (1976) Follicular atresia in the infant human ovary. J. Reprod. Fert. 46, 55-59.

Jagiello, G., Graffeo, J., Ducayen, M. \& Prosser, R. (1977) Further studies of inhibitors of in vitro mammalian oocyte maturation. Fert. Steril. 28, 476-481.

Lacroix, E., Eechante, W. \& Leusen, I. (1974) The biosynthesis of estrogens by cow follicles. Steroids $23,337-356$

Lindsey, A.M. \& Channing, C.P. (1979) Influence of follicular maturation upon the effects of ovine follicle stimulating hormone and luteinizing hormone upon cyclic AMP accumulation of porcine granulosa cells. Biol. Reprod. 20, 473-482.

Louvet, J.P., Harman, S.M., Schreiber, J.R. \& Ross, G.T. (1975) Evidence for a role of androgens in follicular maturation. Endocrinology 97, 336-372.

Lucky, A.W., Schreiber, J.R., Hillier, S.G., Schulman, J.D. \& Ross, G.T. (1977) Progesterone production by cultured preantral rat granulosa cells: Stimulation by androgens. Endocrinology 100, 128-133.

McGaughey, R.W. (1977a) The culture of pig oocytes in minimal medium, and the influence of progesterone and estradiol-17 $\beta$ on meiotic maturation. Endocrinology 100, 39-45.

McGaughey, R.W. (1977b) The maturation of porcine oocytes in minimal defined culture media with varied macromolecular supplements and varied osmolarity. Expl Cell Res. 109, 25-30.

McGaughey, R.W. (1978) In vitro oocyte maturation. In Methods in Mammalian Reproduction, pp. 1-20. Ed. J. C. Daniel, Jr. Academic Press, New York.

McGaughey, R.W. \& Polge, C. (1971) Cytogenetic analysis of pig oocytes matured in vitro.J. exp. Zool. 176, 383-391.

McGaughey, R.W. \& Van Blerkom, J. (1977) Patterns of polypeptide synthesis of porcine oocytes during maturation. Devl Biol. 56, 241-254.

MeGaughey, R.W., Montgomery, D.H. \& Richter, J.D. (1979) Germinal vesicle configurations and patterns of polypeptide synthesis of porcine oocytes from antral follicles of different size, as related to their competency for spontaneous maturation. J. exp. Zool. 209, 239-253.

McNatty, K.P. (1978) Cyclic changes in antral fluid hormone concentrations in humans. Clinics in Endocr. Metab. 7, 577-600.

McNatty, K.P. (1979) Follicular fluid. In The Vertebrate Ovary, pp. 215-259. Ed. R. E. Jones. Plenum Press, New York.

McNatty, K.P. \& Baird, D.T. (1978) The relationship between FSH, androstenedione and oestradiol in human follicular fluid. J. Endocr. 76, 527-531.

Merchant, D.J., Kahn, R.H. \& Murphy, W.H. (1961) Handbook of Cell and Organ Culture. Burgess Publ. Co., Minneapolis.

Moon, Y.S., Dorrington, J.H. \& Armstrong, D.T. (1975) Stimulatory action of follicle stimulating hormone on estradiol $-17 \beta$ by hypophysectomized rat ovaries in organ culture. Endocrinology 97, 244-247.

Moon, Y.S., Tsang, B.K., Simpson, C. \& Armstrong, D.T. (1978) 17 $\beta$-estradiol biosynthesis in cultured granulosa and theca cells of human ovarian follicles: stimulation by follicle-stimulating hormone. J. clin. Endocr. Metab. 47, 263-267.

Moor, R.M. (1977) Sites of steroid production in ovine Graafian follicles in culture. J. Endocr. 73, 143-150.

Moor, R.M., Hay, M.F. \& Seamark, R.F. (1975) The sheep ovary: regulation of steroidogenic, haemodynamic and structural changes in the largest follicle and adjacent tissue before ovulation. $J$. Reprod. Fert. 45, 595-604.

Moore-Smith, D., Tyler, J.P.P. \& Erickson, G.F. (1978) Effects of medium composition and progesterone on maturation in vitro of rabbit oocytes from Graafian follicles of different sizes. J. Reprod. Fert. 54, $393-400$.

Nekola, M.V. \& Smith, D.M. (1974) Oocyte maturation and follicle cell viability in vitro. Eur. J. Obstet, Gynec. Reprod. Biol., Suppl. 4, S125-S131.

Nie, N., Hull, C., Jenkins, J., Steinbrenner, K. \& Brent, D. (1975) Statistical package for the social sciences, 2nd edn, p. 422. McGraw-Hill, New York.

Nimrod, A. \& Lindner, H.R. (1976) A synergistic effect of androgen on the stimulation of progesterone secretion by FSH in cultured rat granulosa cells. Molec. cell. Endocr. 5, 315-320.

Payne, R.W. \& Runser, R.H. (1958) The influence of estrogen and androgen on the ovarian response of hypophysectomized immature rats to gonadotropins. Endocrinology 62, 313-321.

Rice, C. \& McGaughey, R.W. (1980) Interactions between the granulosa cell and the oocyte in vitro. $J$. Anim. Sci. 51 , Suppl. Abstr. 521.

Richter, J.D. \& McGaughey, R.W. (1979) Specificity of inhibition by steroids of porcine oocyte maturation in vitro. J. exp. Zool. 209, 81-90.

Schomberg, D.W. (1979) Steroidal modulation of steroid secretion in vitro: an experimental approach to intra-follicular regulatory mechanisms. $A d v$. exp. Med. 112, 155-168.

Schomberg, D.W., Stouffer, R.L. \& Tyrey, L. (1976) Modulation of progestin secretion in ovarian cells by $17 \beta$-hydroxy- $5 \alpha$-androstan-3-one (dihydrotestosterone): a direct demonstration in monolayer culture. Biochem. Biophys. Res. Commun. 68, 77-81.

Schuetz, A.W. (1979) The somatic-cell germ complex: interactions and transformations in relation to oocyte maturation. Adv. exp. Med. 112, 307-314.

Short, R.V. (1960) Steroids present in the follicular fluid of the mare. Endocrinology 20, 147-156.

Short, R.V. (1962) Steroids in the follicular fluid and the corpus luteum of the mare: a "two-cell type" theory of ovarian steroid synthesis. J. Endocr. 24, 59-63.

Speroff, L. \& van Wielle, R.L. (1971) Regulation of the 
human menstrual cycle. Am. J. Obstet. Gynec. 109, 234-247.

Stern S. \& Wassarman, P.M. (1974) Protein synthesis during meiotic maturation of the mammalian oocyte. J. Cell Biol. 59, 335a, Abstr.

Stone, S.L., Pomerantz, S.E., Schwartz-Kripner, A. \& Channing, C.P. (1978) Inhibitor of oocyte maturation from porcine follicular fluid: further purification and evidence for reversible action. Biol. Reprod. 19, 585-592.

Thanki, K.H. \& Channing, C.P. (1978) Effects of follicle-stimulating hormone and estradiol upon progesterone secretion by porcine granulosa cells in tissue culture. Endocrinology 103, 74-80.

Thibault, C. (1977) Are follicular maturation and oocyte maturation independent processes? J. Reprod. Fert. $51,1-15$.

Tsafriri, A. (1978) Inhibition of nuclear maturation of isolated rat oocytes by follicular constituents. Annls Biol. anim. Biochem. Biophys. 18, 523-526.

Tsafriri, A. (1979) Oocyte maturation in mammals. In The Vertebrate Ovary, pp. 409-442. Ed. E. Jones. Plenum Press, New York.

Tsafriri, A. \& Channing, C.P. (1975) An inhibitory influence of granulosa cells and follicular fluid upon porcine oocyte meiosis in vitro. Endocrinology 96, 922-927.

Tyler, J.P.P., Moore-Smith, D. \& Biggers, J.D. (1980) Effects of steroids on oocyte maturation and atresia in mouse ovarian fragments in vitro. J. Reprod. Fert. $58,203-212$.

Wassarman, P.M. \& Turner, P.E. (1976) Effect of dithiothreitol on meiotic maturation of mouse oocytes in vitro: dependence of the effect on $\mathrm{N}^{6}$, $\mathrm{O}^{2}$-dibutyryl adenosine $3^{\prime}, 5^{\prime}$-cyclic monophosphate. J. exp. Zool. 196, 183-188.

Received 24 October 1980 